\title{
Effect of Grinding Time of Mill Scale on the Physicochemical Properties of Produced Briquettes and Its Reduction via Hydrogen
}

\author{
Naglaa Ahmed El-Hussiny', Hassan Hussein Abdul-Wahab ${ }^{2}$, Mohamed Mahmoud Ali², \\ Abdud-Lattif Abdel-Motagally Omar ${ }^{3}$, Mohamed El-Menshawi Hussien Shalabi', \\ Mohamed Reda Moharm ${ }^{3}$ \\ ${ }^{1}$ Central Metallurgical Research and Development Institute (CMRDI), Cairo, Egypt \\ ${ }^{2}$ Faculty of Engineer, Qena, Al-Azhar University, Cairo, Egypt \\ ${ }^{3}$ Faculty of Engineer, Al-Azhar University, Cairo, Egypt \\ Email: shalabimeh@hotmail.com
}

Received 30 July 2014; revised 15 September 2014; revised 18 October 2014

Copyright (C) 2014 by authors and OALib.

This work is licensed under the Creative Commons Attribution International License (CC BY).

http://creativecommons.org/licenses/by/4.0/

(c) (i) Open Access

\section{Abstract}

This study deals with the grinding of mill scale in a laboratory ball mill for different milling time then briquetted by using $2 \%$ molasses as a binder and investigates the effect of grinding of mill scale for different time on the physicochemical properties and the reduction degree of the mill scale briquettes via hydrogen. Diffusion process control equation was applied and the energy of activation was calculated $=28.33 \mathrm{~kJ} / \mathrm{mole}$.

\section{Keywords}

Grinding Time, Mill Scale, Reduction via $\mathbf{H}_{2}$

Subject Areas: Inorganic Chemistry, Material Experiment

\section{Introduction}

In integrated steelmaking processes, some dusts, sludges, mill scale etc., commonly called residual materials, are inevitably generated along with the production of steel. The steelmaking by-products very rich in iron $(\approx 72 \% \mathrm{Fe})$ are currently produced in large quantities and represent a potential of almost 5 million tons in the world [1] [2]. Dumping of residual materials is not allowed by environmental protection regulations [3]. Generally, these byproducts are recycled by the metallurgical processes such as the blast furnace or the direct reduction reactors that use coal as the reducing agent to produce pre-reduced pellets intended for remelt in electric steel plants. Besides the steelmaking, recycling part of these by-products is already supported by the powder metallurgy where the economic recovery is more favorable [1] [2].

How to cite this paper: El-Hussiny, N.A., et al. (2014) Effect of Grinding Time of Mill Scale on the Physicochemical Properties of Produced Briquettes and Its Reduction via Hydrogen. Open Access Library Journal, 1: e1016.

http://dx.doi.org/10.4236/oalib.1101016 
Mill scale is a steelmaking by-product from the rolling mill in the steel hot rolling process. Mill scale contains both iron in elemental form and three types of iron oxides: Wustite (FeO), Hematite $\left(\alpha-\mathrm{Fe}_{2} \mathrm{O}_{3}\right)$ and Magnetite $\left(\mathrm{Fe}_{3} \mathrm{O}_{4}\right)$. The chemical composition of mill scale varies according to the type of steel produced and the process used. The iron content is normally around $70 \%$, with traces of non-ferrous metals and alkaline compounds. The reduction of rolling mill scale to sponge iron powder is a new way to take advantage of a cheap by-product of the steelmaking industry, yielding sponge iron that can be re-used to the electric furnace as metallic charge for steelmaking to obtain a product with a lower residual content and improved properties [3]-[5].

Mechanical activation pretreatment of minerals by intensive milling can improve the efficiency of subsequent processes such as leaching, reduction, chemical synthesis, etc. Consequential benefits of mechanical activation, besides higher efficiencies may include lower reaction temperatures and enhanced kinetics. As a result, the subsequent processing can be performed in simpler and less expensive reactors with shorter reaction time [6]-[8]. Several factors, most importantly the formation of new and additional surface area as well as creation of lattice defects, are responsible for the mentioned improvements [6] [9]-[14]. Different types of milling apparatus such as ball mills, planetary mills, vibratory mills, pin mills and rolling mills may be used for milling operations [15].

Mechanical treatment in a high energy mill generates a stress field within solids. Stress relaxation can occur via several channels: 1) heat release; 2) development of surface area as a result of brittle fracture of the particles; 3) generation of various sorts of structural defects and 4) stimulation of chemical reaction within solids. All relaxation channels cause changes in the reactivity of the solid substance under treatment, which is why the resulting action is called mechanical activation [16]. The concentration of the mechanically induced defects and their spatial distribution depend upon the condition of the energy transfer in the mill. The concentration and distribution of the mechanically induced defects can be also influenced by varying the external conditions of stress. The creation of defects enhances the stored energy (enthalpy) in the solids and consequently causes a decrease of activation barrier for the process and/or subsequent processes [17]. A large number of studies have been devoted to the understanding of the influence of the grinding variables and conditions on the structural changes of mechanically-activated material. Structural changes of inorganic oxides have been shown to be intensified with increasing grinding media density, acceleration and duration of milling in a planetary mill [18]. It has been further reported that the crystallite size decreased exponentially with increasing milling time and the strain increased by extending activation time during mechanical activation of ilmenite [19]. A comparative study of the influence of attritor and ball vibratory mills on the reactivity of sulphide minerals was carried out by Balaz et al. [20]. $\gamma-\mathrm{Fe}_{2} \mathrm{O}_{3}$ samples ground with smaller amplitude in a vibratory mill showed higher reactivity [21].

The aim of this work is to investigate the effect of grinding duration on the physical quality and the kinetic reduction behavior of mill scale briquettes by hydrogen.

\section{Experimental Procedures}

\subsection{Characterization of Mill Scale}

\subsubsection{Sieve Analyses}

Mill scale used in this experiment delivered from Iron and Steel Co. This mill scale was grind in laboratory ball mill for different hours from 1 hour up to 4 hours. This mill scale before and after grinding was subjected to sieve analysis by Tyler standard sieve set with electric shaker and the results is illustrated in Figure 1 and the mean size of mill scale is present in Table 1.

\subsubsection{Chemical Analyses}

The chemical analysis of mill scale shows that it contains Fe total 69.33 weight\% in the form $\left(\mathrm{Fe}_{2} \mathrm{O}_{3} 70\right.$ weight $\%, \mathrm{Fe}_{3} \mathrm{O}_{4} 17.26$ weight\% and $\mathrm{FeO} 7.83$ weight \%). Sulphur 0.33 weight\%, Phosphorus 0.22 weight\%, $\mathrm{MnO} 0.66$ weight $\%, \mathrm{SiO}_{2} 1.92$ weight $\%$ and carbon 0.04 weight $\%$.

\subsubsection{X-Ray Analysis}

While the X-ray analysis of mill scale is illustrated in Figure 2, as it is clear from this figure that mill scale mainly consists of magnetite, wustite, iron, quartz and hematite.

\subsection{Preparation of the Briquettes and Its Physical Properties}

The fine mill scale particles (10 g) after grinding for different time in laboratory ball mill are mixed with 2\% 
Table 1 . The mean size of mill scale after grinding for different time.

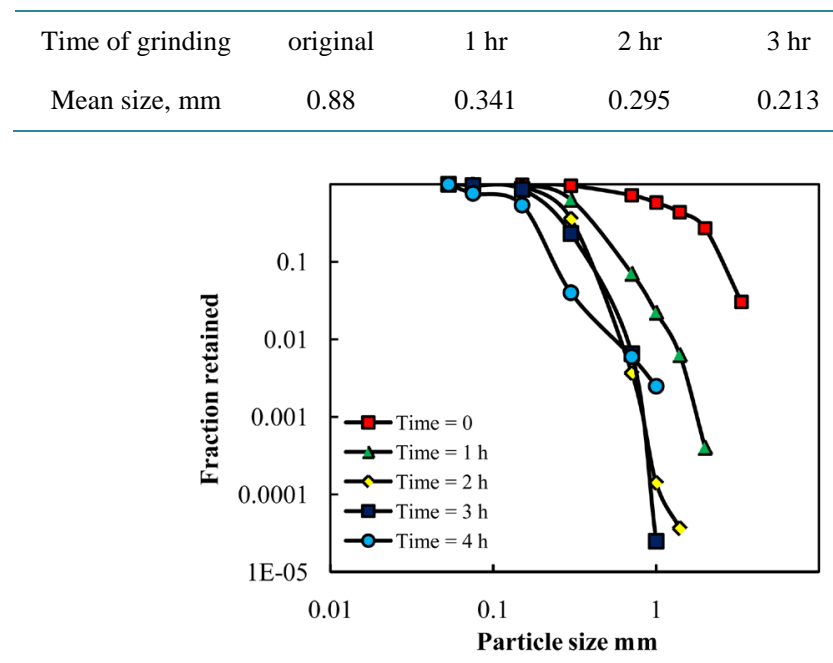

Figure 1. Sieve analysis of mill scale grinding in ball mill for different time.

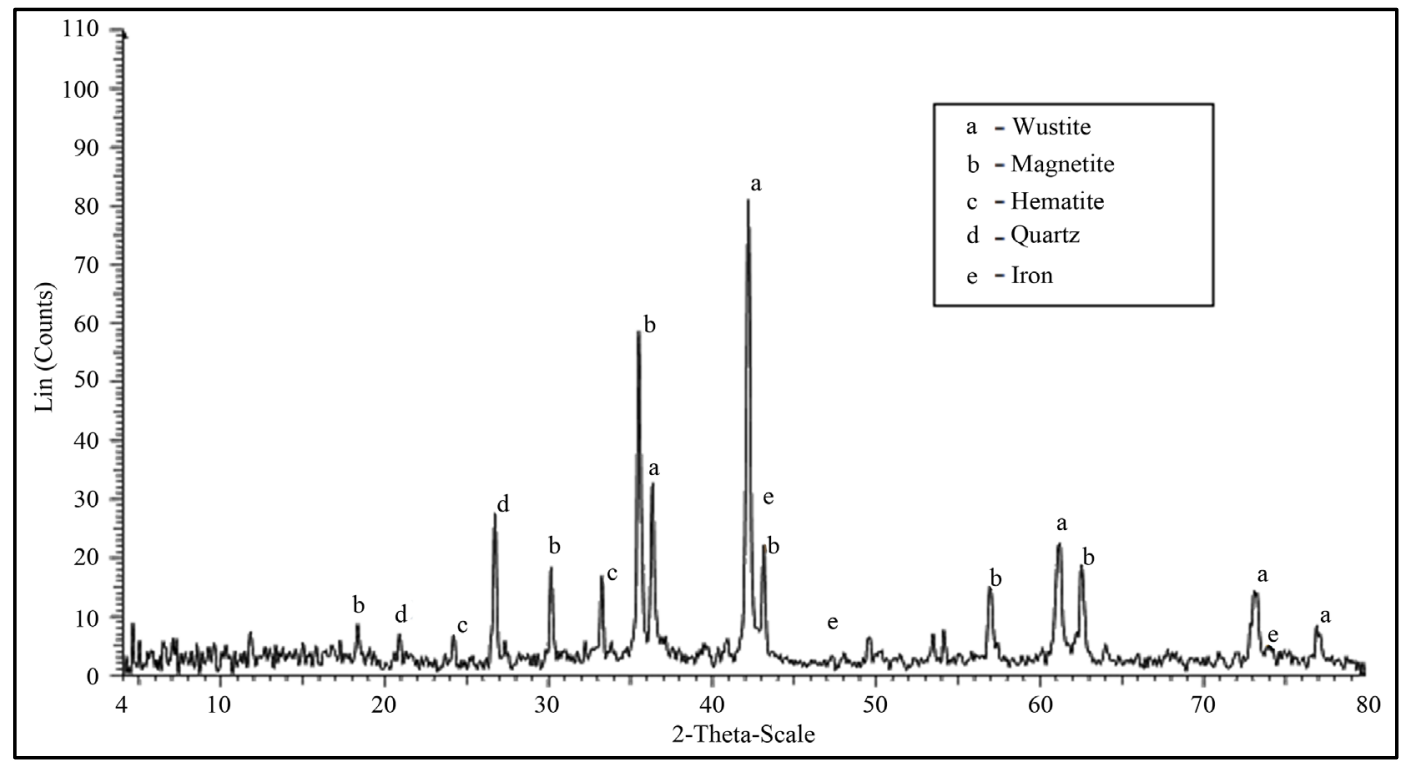

Figure 2. X-ray analysis of mill scale sample.

molasses and then pressed in the mould (12 mm diameter and a height $22 \mathrm{~mm}$ using MEGA.KSC-10 hydraulic press. Under different pressure (the pressure ranges from $75 \mathrm{MPa}$ up to $250 \mathrm{MPa}$ ). The produced briquettes were subjected to drop damage resistance tests and compressive strength tests. The drop damage resistance indicates how often green briquettes can be dropped from a height $46 \mathrm{~cm}$ before they show perceptible cracks or crumble. Ten green briquettes are individually dropped on to a steel plate. The number of drops is determined for each briquette. The arithmetical average values of the crumbing behavior of the ten briquettes yield the drop damage resistance for these briquettes, while the average compressive strength is done by compressed 10 briquettes between parallel steel plates up to their breaking [22].

\subsection{Reduction Procedures}

The reduction of mill scale briquette with hydrogen was performed in thermogravimetric apparatus. This scheme is similar to that present elsewhere [23] (Figure 3). It consisted of a vertical furnace, electronic balance for 


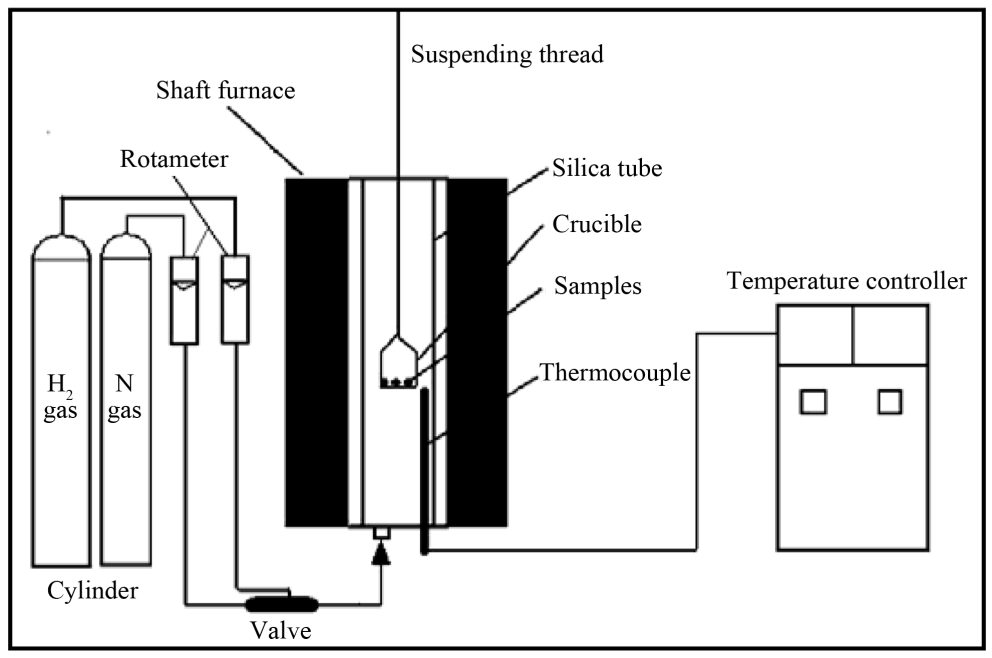

Figure 3. Schematic diagram of the reduction apparatus.

monitoring the weight change of reacting sample and temperature controller. The sample was placed in a nickel chrome crucible which was suspended under the electronic balance by $\mathrm{Ni}-\mathrm{Cr}$ wire. The furnace temperature was raised to the required temperature $\left(650^{\circ} \mathrm{C}-950^{\circ} \mathrm{C}\right)$ and maintained constant to $\pm 5^{\circ} \mathrm{C}$. Then samples were placed in hot zone.

The nitrogen flow rate was $0.5 \mathrm{l} / \mathrm{min}$ pass through furnace in all the experiments at initial time air should be removed before each experiment and also after the end of reduction. The weight of the sample was continuously recorded at the end of the run; the samples were withdrawn from the furnace and put in the desiccators.

The percentage of reduction was calculated according to the following Equation (1):

$$
\text { Percent of reduction }=[(W o-W t) \times 100 / \text { Oxygen mass }]
$$

where:

Wo: the initial mass of mill scale sample after removal of moisture;

$W t$ : mass of sample after each time, $t$;

Oxygen mass: indicates the mass of oxygen percent in mill scale in form $\mathrm{FeO} \& \mathrm{Fe}_{2} \mathrm{O}_{3}$.

\section{Results and Discussions}

\subsection{Effect of the Pressing Load with Constant Amount of Molasses on the Quality of the Wet and Dry Mill Scale Briquettes}

Figures 4-7 show the relation between the change of pressing load at constant amount of molasses (2\%) on the drop damage resistance and compressive strength of the wet and dry briquette. It is evident that as the pressing pressure load increased both the drop damage resistance and compressive strength increased. This may be due to the fact that increase pressure load increase the compaction of briquette and subsequently the Vander Waals forces increased [24] [25], also this may be due to the increase of briquetting pressure leads to progressive crushing of the macropores [26]. Also from these figures, it is clear that as the size of mill scale decrease (increase of time of grinding) both drop damage resistance and compressive strength of wet and dry briquette increased.

\subsection{Effect of the Grinding Time on the Reduction Percentage}

Figure 8 illustrates the effect of change milling time on the degree of reduction of mill scale briquette at $900^{\circ} \mathrm{C}$ (pressing load 260.129667 MPa) for different time and at $1 \mathrm{l} / \mathrm{min}$. hydrogen flow rate. From this figure it is clear that the extent of the reduction increased as the milling time increased from $1 \mathrm{hr}$. up to $4 \mathrm{hr}$, this may be attributed to additional surface area as well as creation of lattice defects by the action of change milling time [6] [9]-[14]. 


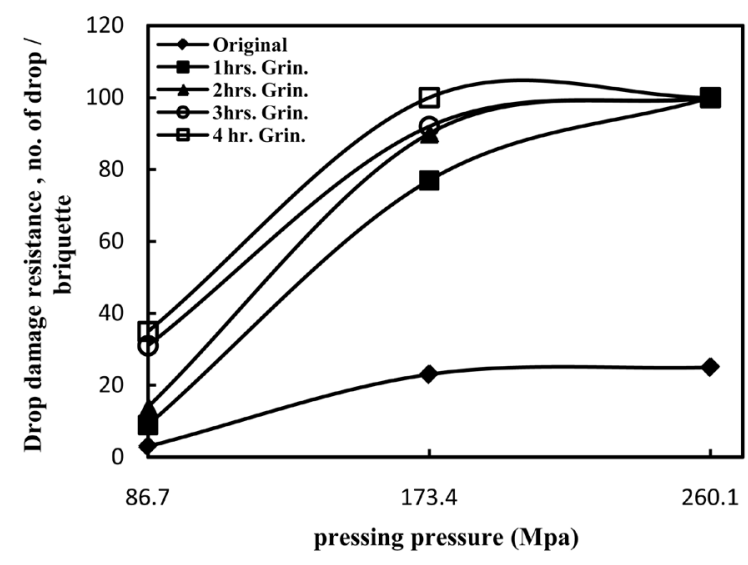

Figure 4. Effect of grinding time on drop damage resistance of mill scale briquette in green state under different pressing pressure.

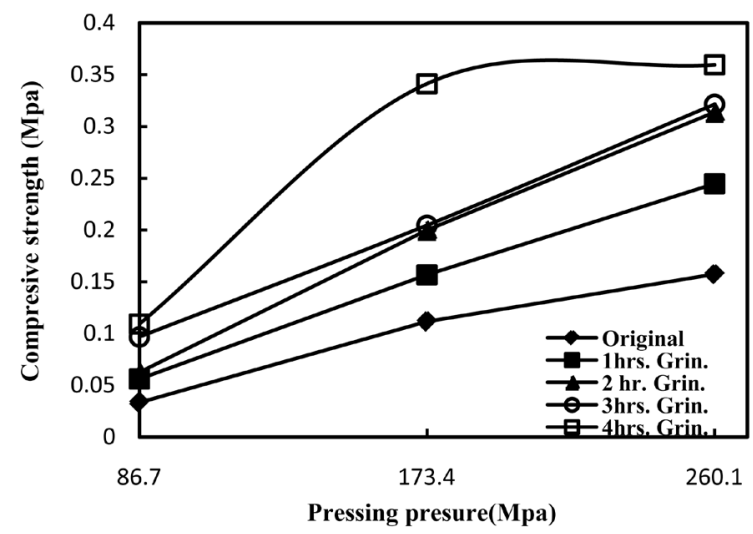

Figure 5. Effect of grinding time on compressive strength of mill scale briquette in green state under different pressing pressure.

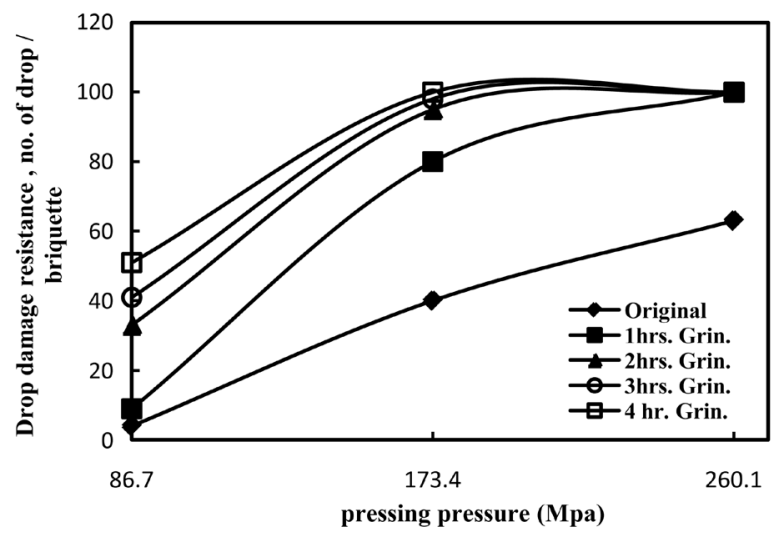

Figure 6. Effect of grinding time on drop damage resistance of mill scale briquette in dry state under different pressing pressure.

\subsection{Effect of Hydrogen Flow Rate on the Reduction Percentage}

Figure 9 illustrates the relation between the reduction percentage and hydrogen flow rate when the reduction was done at constant temperature $\left(900^{\circ} \mathrm{C}\right)$ and constant weight of the sample. It is clear that as the flow rate of hydrogen increased the reduction percentage increased. This may be the increase of flow rate leads to an in- 


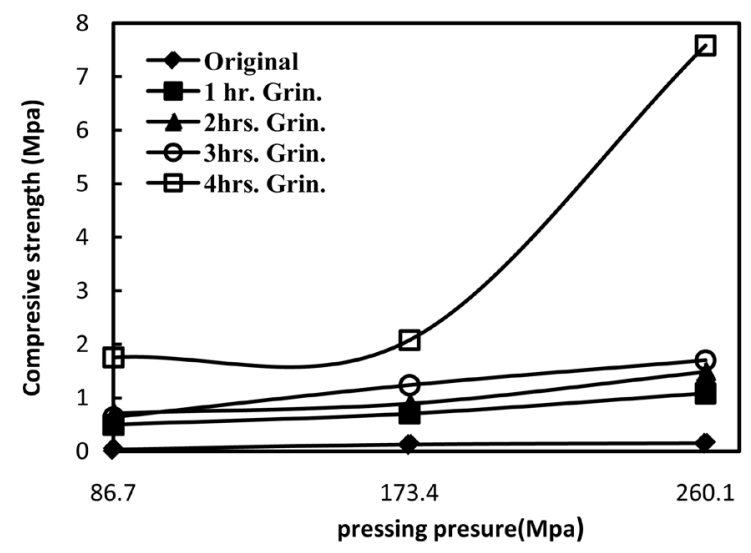

Figure 7. Effect of grinding time on compressive strength of mill scale briquette in dry state under different pressing pressure.

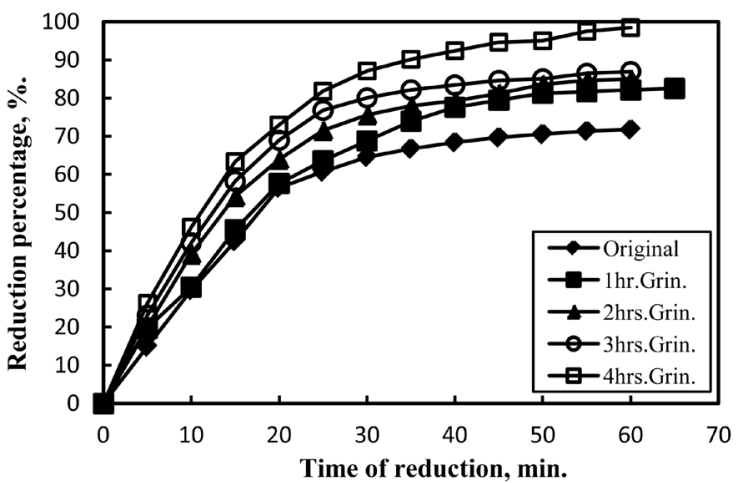

Figure 8. Effect of grinding time on the reduction percentage of mill scale briquette at $900^{\circ} \mathrm{C}$ (pressing load 260.129667 MPa) for different time and at $1 \mathrm{l} / \mathrm{min}$ hydrogen flow rate.

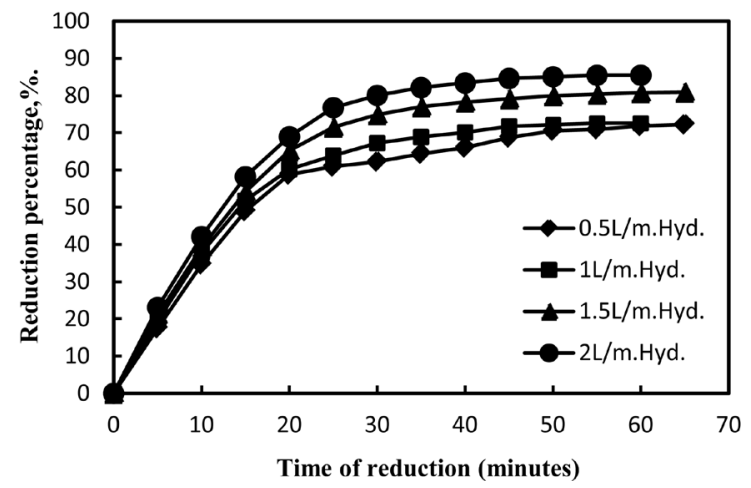

Figure 9. Effect of hydrogen flow rate on the reduction percentage of mill scale briquette at different time of reduction at $900^{\circ} \mathrm{C}$ (pressing load 260.129667 MPa).

crease of number of hydrogen mole in the bulk phase, which in turn leads to the raise of hydrogen adsorption and subsequently the rate of reaction increased [27] or the increase of flow rate increased the gas diffusion across the boundary layer subsequently the reduced ion increased [28]. Also may be the higher flow rate prevailing in the reaction zone which enhances the rate of hydrogen absorption and subsequently the rate of chemical reaction steps increased [29]. But from the economic view, it is preferred to use $1.5 \mathrm{l} / \mathrm{min}$. hydrogen flow rate in the rest of this investigation. 


\subsection{Effect of Varying Reduction Temperature on the Reduction Percentage}

The reduction was carried out at different temperatures ranging from $600^{\circ} \mathrm{C}$ up to $950^{\circ} \mathrm{C}$, where the weight of the briquette were constant and the hydrogen flow rate $=1.5$ liter $/ \mathrm{min}$. The results of the investigation are shown in Figure 10 for the briquette binding by 2\% molasses. It is clear that the increase of temperature favors the reduction rate and degree. The analyses of the curve relating the reduction percentage and time of reduction, shows that each curve has 3 different values of reduction rates. The first value is high, while the second is somewhat slower and the third is slowest one. The increase of reduction percentage with rise of temperature may be due to the increase of number of reacting moles having excess of energy which leads to the increase of reduction rate [27] [30]. Also the raise of temperature leads to an increase of the rate of mass transfer of the diffusion and rate of desorption [28] [31].

\subsection{Kinetics of the Reduction Process}

Kinetic studies for estimation of apparent activation energies were carried out for mill scale briquettes at different temperatures from $600^{\circ} \mathrm{C}$ up to $950^{\circ} \mathrm{C}$ for different time intervals in the range of 0 - 65 minutes.

1) By using diffusion process control equation (Jander and Anorg Equation (2)) [32]

$$
\left(1-(1-R)^{1 / 3}\right)^{2}=k t
$$

where $R$ is fractional reduction, $t$ is time of reduction, $k$ is the rate constant.

Figure 11 illustrates the relation between $\left(1-(1-R)^{1 / 3}\right)^{2}=k t$ against time of reduction for different reduc-

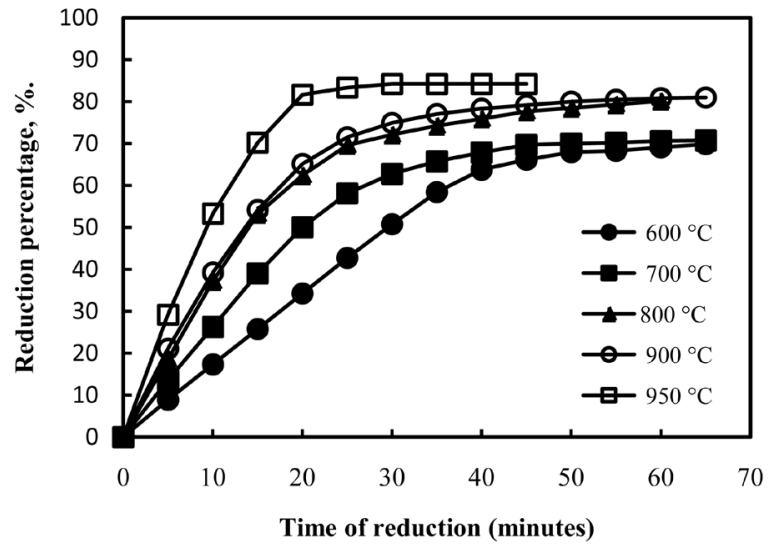

Figure 10. Effect of temperature change on the reduction percentage of mill scale briquette at different time of reduction (pressing load 260.129667 MPa.)

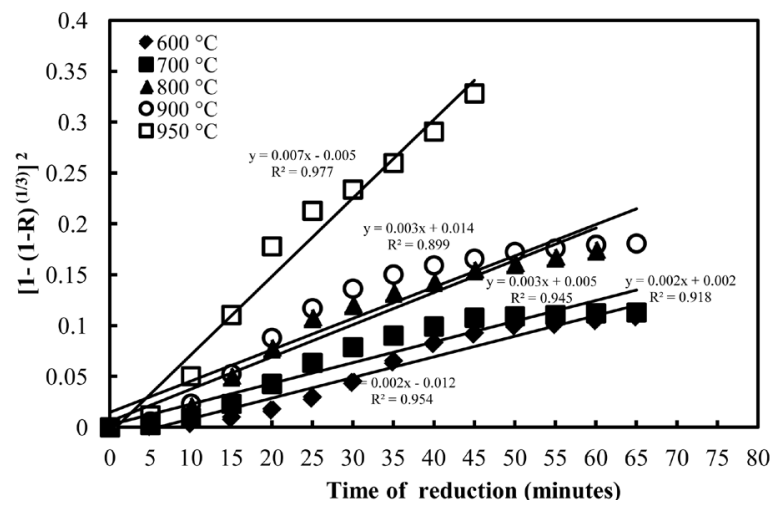

Figure 11. The relationship between time of reduction and $\left.\left[1-(1-\mathrm{R})^{(1 / 3)}\right)\right]^{2}$ at different temperatures. 
tion temperature. From which it is clear that the relationship is represented by straight line.

The natural logarithms were used according to the Arrhenius equation to calculate the activation energies of reduction reaction by using the calculated rate constant $k$.

$$
\begin{gathered}
k=k_{0} \exp \left(-\frac{E}{R T}\right) \\
\ln k=\ln k^{0}-\frac{E}{R T}
\end{gathered}
$$

where $k_{0}$ is the coefficient; $E$ is the apparent reduction activation energy; $R$ is the universal gas constant [8.314 $\times$ $\left.10^{-3} \mathrm{~kJ} /(\mathrm{mol} \cdot \mathrm{K})\right] ; T$ is the absolute temperature. The relationships between the natural logarithm of reduction rate constant and the reciprocal of absolute temperature for mill scale briquettes are shown in Figure 12, from which it is clear that briquette has activation $28.33 \mathrm{~kJ} / \mathrm{mole}$.

\subsection{X-Ray Analyses of the Reduced Briquette}

Figure 13 and Figure 14 show the X-ray analyses of the reduced mill scale briquette at $600^{\circ} \mathrm{C}$ and $950^{\circ} \mathrm{C}$ respectively. From which it is clear that the main phases in the reduced briquette are Iron Syn-Fe, Hematite and Magnetite. But Iron oxide (FeO) phase is present at $950^{\circ} \mathrm{C}$ rather than in case at $600^{\circ} \mathrm{C}$.

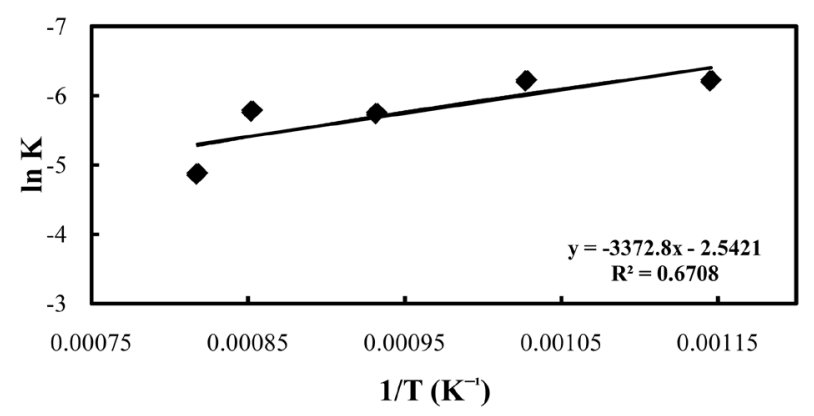

Figure 12. The relation between the reciprocal of absolute temperature $1 / T$ and $\ln K$ (Arrhenius plot for reduction reaction).

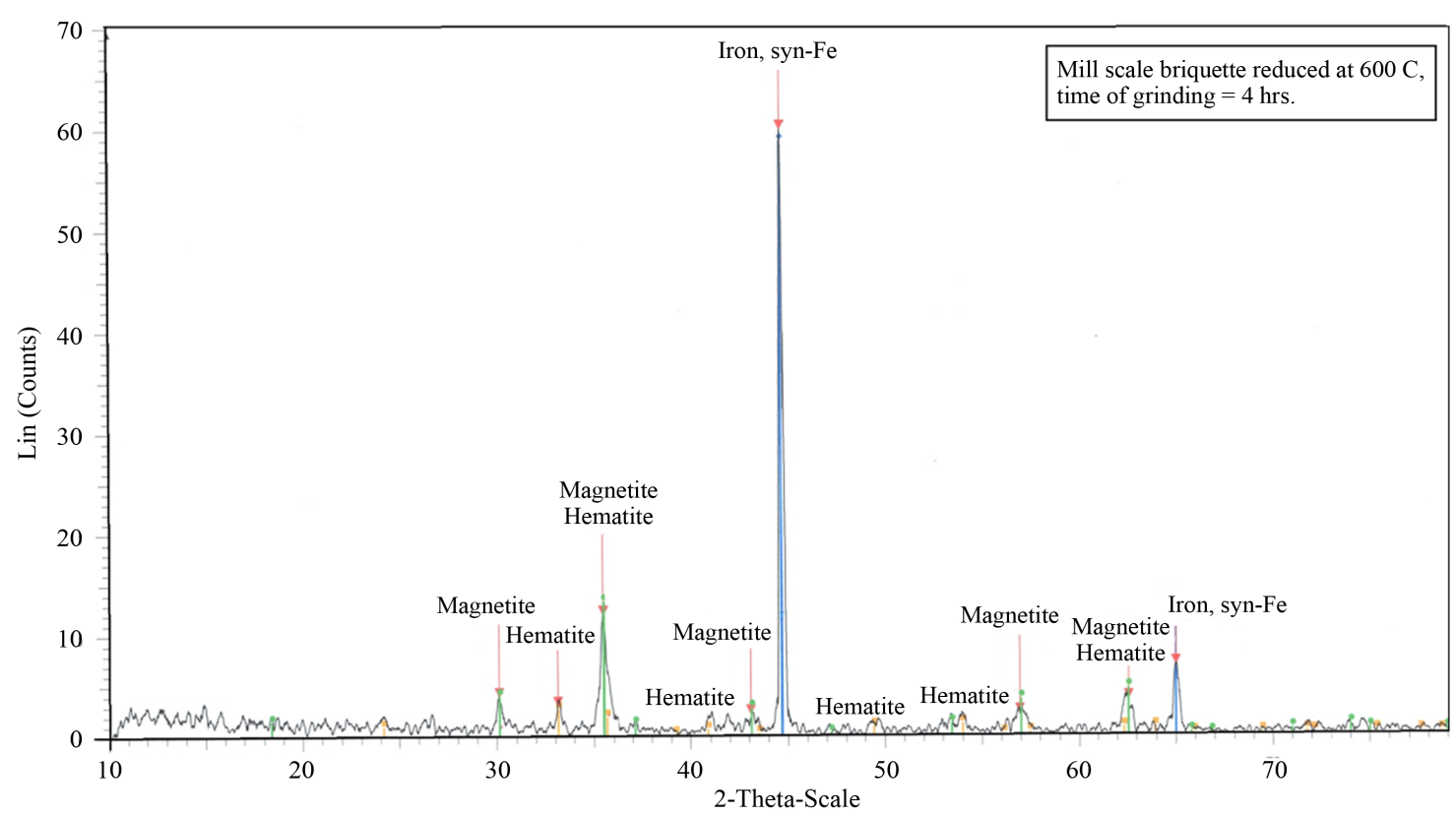

Figure 13. X-ray analysis of mill scale briquette reduced at $600^{\circ} \mathrm{C}$. 


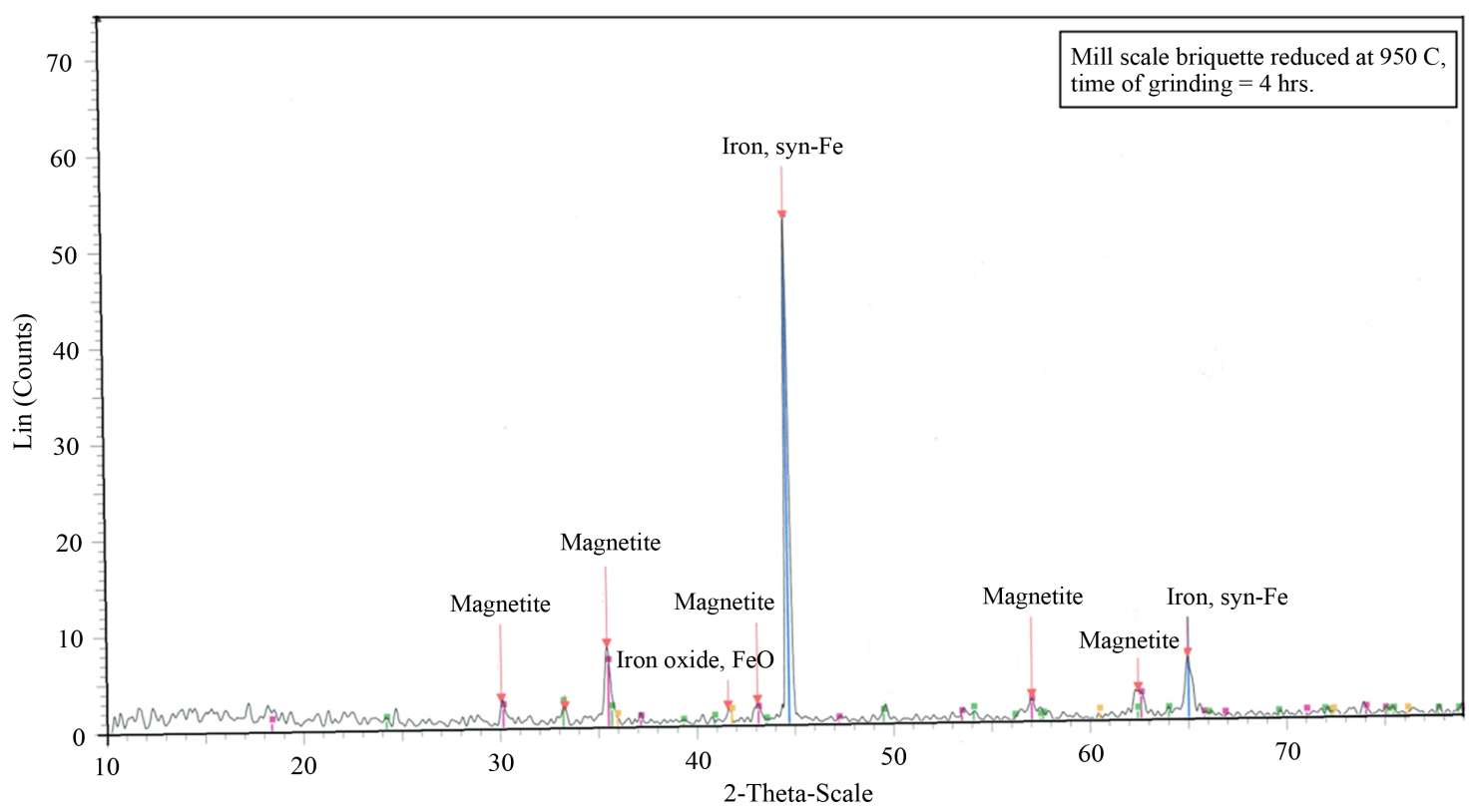

Figure 14. X-ray analysis of mill scale briquette reduced at $950^{\circ} \mathrm{C}$.

\section{Conclusions}

The reduction of mill scale grinding for different time ranging between $1 \mathrm{hr}$ up to $4 \mathrm{hr}$. in the form of briquette (pressing load about $260 \mathrm{MPa}$ ) by hydrogen at varying temperatures from $600^{\circ} \mathrm{C}$ up to $950^{\circ} \mathrm{C}$ for different time and at $1.5 \mathrm{l} / \mathrm{min}$ hydrogen flow rate indicated that:

1) The reduction rates increased with increasing temperature of the reduction up to $950^{\circ} \mathrm{C}$.

2) Diffusion process control equation (Jander equation) $\left(1-(1-R)^{1 / 3}\right)^{2}=k t$ was applied and the energy of activation was calculated $=28.33 \mathrm{~kJ} / \mathrm{mole}$.

\section{References}

[1] Bienvenu, Y. and Rodrigues, S. (2007) Manufacture of Metal Powders from Pulverulent Waste. ENSMP, Centre des matériaux, CNRS UMR 7633, France.

[2] Benchiheub, O., Mechachti, S., Serrai, S. and Khalifa, M.G. (2010) Elaboration of Iron Powder from Mill Scale. Journal of Materials and Environmental Science, 1, 267-276.

[3] Camci, L., Aydin, S. and Arslan, C. (2002) Reduction of Iron Oxides in Solid Wastes Generated by Steelworks. Turkish Journal of Engineering and Environmental Sciences, 26, 37-44.

[4] Martín, M.I., López, F.A., Rabanal, M.E. and Torralba, J.M. (2010) Production of Sponge Iron Powder by Reduction of a By-Product of the Steelmaking Industry. PM2010 World Congress-Water Atomized Powders, v. 1.

[5] Park, J.-W., Ahn, J.-C., Song, H., Park, K., Shin, H. and Ahn, J.-S. (2002) Reduction Characteristics of Oily Hot Rolling Mill Sludge by Direct Reduced Iron Method. Resources, Conservation and Recycling, 34, 129-140. http://dx.doi.org/10.1016/S0921-3449(01)00098-2

[6] Balaz, P., Takacs, L., Luxova, M., Godocikova, E. and Ficeriova, J. (2004) Mechanochemical Processing of Sulphidic Minerals. International Journal of Mineral Processing, 245, S365-S371. http://dx.doi.org/10.1016/j.minpro.2004.07.007

[7] Hu, H., Chen, Q., Yin, Z. and Zhang, P. (2003) Thermal Behaviors of Mechanically Activated Pyrites by Thermogravimetry (TG). Thermochimica Acta, 398, 233-240. http://dx.doi.org/10.1016/S0040-6031(02)00390-8

[8] Godocikova, E., Balaz, P. and Boldizarova, E. (2002) Structural and Temperature Sensitivity of the Chloride Leaching of Copper, Lead and Zinc from a Mechanically Activated Complex Sulphide. Hydrometallurgy, 65, 83-93. http://dx.doi.org/10.1016/S0304-386X(02)00094-4

[9] Maurice, D. and Hawk, J.A. (1999) Ferric Chloride Leaching of a Mechanically Activated Pentlandite-Chalcopyrite 
Concentrate. Hydrometallurgy, 52, 289-312. http://dx.doi.org/10.1016/S0304-386X(99)00021-3

[10] Maurice, D. and Hawk, J.A. (1999) Simultaneous Autogenous Milling and Ferric Chloride Leaching of Chalcopyrite. Hydrometallurgy, 51, 371-377. http://dx.doi.org/10.1016/S0304-386X(98)00088-7

[11] Ficeriová, J., Baláž, P. and Boldižárová, E. (2005) Combined Mechanochemical and Thiosulphate Leaching of Silver from a Complex Sulphide Concentrate. International Journal of Mineral Processing, 76, 260-265. http://dx.doi.org/10.1016/j.minpro.2005.01.005

[12] Baláž, P., Boldižárová, E., Achimovičová, M. and Kammel, R. (2000) Leaching and Dissolution of a Pentlandite Concentrate Pretreated by Mechanical Activation. Hydrometallurgy, 57, 85-96. http://dx.doi.org/10.1016/S0304-386X(00)00102-X

[13] Welham, N.J. (2001) Mechanochemical Processing of Enargite $\left(\mathrm{Cu}_{3} \mathrm{AsS}_{4}\right)$. Hydrometallurgy, 62, 165-173. http://dx.doi.org/10.1016/S0304-386X(01)00195-5

[14] Baláž, P., Ficeriová, J. and Leon, C.V. (2003) Silver Leaching from a Mechanochemically Pretreated Complex Sulfide Concentrate. Hydrometallurgy, 70, 113-119. http://dx.doi.org/10.1016/S0304-386X(03)00051-3

[15] Baláž, P. (2003) Mechanical Activation in Hydrometallurgy. International Journal of Mineral Processing, 72, $341-354$. http://dx.doi.org/10.1016/S0301-7516(03)00109-1

[16] Boldyrev, V.V. and Tkáčová, K. (2000) Mechanochemistry of Solids: Past, Present, and Prospects. Journal of Materials Synthesis and Processing, 8, 121-132. http://dx.doi.org/10.1023/A:1011347706721

[17] Steinike, U. and Tkáčová, K. (2000) Mechanochemistry of Solids-Real Structure and Reactivity. Journal of Materials Synthesis and Processing, 8, 197-203. http://dx.doi.org/10.1023/A:1011364110355

[18] Karagedov, G.R. and Lyakhov, N.Z. (2003) Mechanochemical Grinding of Inorganic Oxides. KONA Powder and Particle Journal, 21, 76-86. http://dx.doi.org/10.14356/kona.2003011

[19] Welham, N.J. and Llewellyn, D.J. (1998) Mechanical Enhancement of the Dissolution of Ilmenite. Minerals Engineering, 11, 827-841. http://dx.doi.org/10.1016/S0892-6875(98)00070-3

[20] Baláž, P., Huhn, H.J., Tkáčová, K. and Heegn, H. (1988) Laugungsverhalten und physico-chemische Eigenschaften von in unterschiedlichen Mullen vorbehandeltemchalkopyrite. Erzmetall, 41, 325-331.

[21] Senna, M. (1983) Criteria of Activation of Powdery Materials by a Preliminary Mechanical Treatment. KONA Powder and Particle Journal, 1, 48-52. http://dx.doi.org/10.14356/kona.1983009

[22] Mayer, K. (1980) Pelletization of Iron Ores. Springer-Verlag, Berlin, Heidelberg.

[23] El-Hussiny N.A. and Shalabi, M.E.H. (2011) A Self-Reduced Intermediate Product from Iron and Steel Plant Waste Material Using a Briquetting Process. Powder Technology, 205, 217-223. http://dx.doi.org/10.1016/j.powtec.2010.09.017

[24] Mohamed, F.M., Ahmed, Y.M.Z. and Shalabi, M.E.H. (2004) Environmental Issues and Waste Management in Energy and Mineral Production SWEMP. 567-573.

[25] Mangena, S.J. and Cann, V.M. (2007) Binderless Briquetting of Some Selected South African Prime Coking, Blend Coking and Weathered Bituminous Coals and the Effect of Coal Properties on Binderless Briquetting. International Journal of Coal Geology, 71, 303-312. http://dx.doi.org/10.1016/j.coal.2006.11.001

[26] Ingles, O.G. (1962) Microstructure in Binderless Briquetting. In: Knepper, W.A., Ed., Agglomeration, Interscience Publishers, New York, 29-53.

[27] Shalabi, M.E.H. (1973) Kinetic Reduction of El-Baharia Iron Ore and Its Sinter in Static Bed by Hydrogen. El-Tabbin Metallurgical Institute for Higher Studies, Cairo.

[28] Sayed, S.A., Khalifa, G.M., El-Faramawy, E.S.R. and Shalabi, M.E.H. (2002) Kinetic Reduction of Low Manganes Iron Ore by Hydrogen. Egyptian Journal of Chemistry, 45, 47-66

[29] Sayed, S.A., Khalifa, M.G., El-Faramawy, E.S.R. and Shalabi, M.E.H. (2001) Reductions Kinetic of El-Baharia Iron Ore in a Static Bed. Gospodarka Surowcami Mineranymi, 17, 241-245.

[30] Shalabi, M.E.H., Mohamed, O.A., Abdel-Khalek, N.A. and El-Hussiny, N.A. (1997) The Influence of Reduced Sponge Iron Addition on the Quality of Produced Iron Ore Sinter. Proceeding of the XXIMPC, Aachen, 21-26 September 1997, 362-376.

[31] El-Hussiny, N.A., Abdel-Khalek, N.A., Morsi, M.B., Mohamed, O.A., Shalabi, M.E.H. and Baeka, A.M. (1996) Influence of Water Amount Added on the Sintering Process of Egyptian Iron Ore. Gornictwo, 231, 93-115.

[32] Jander, W. and Anorg, Z. (1927) Kinetic Model for Solid-State Reactions. Zeitschrift für Anorganische und Allgemeine Chemie, 163, 1-30. 